\title{
IMPACT OF CLIMATE CHANGE ON ONION CROP
}

\author{
Navanath K. Agale ${ }^{1}$ and Bhalchandra B. Thaware ${ }^{2}$ \\ 1 Shri Dnyaaneshwar Mahavidyalay, Newasa \\ ${ }^{2}$ Chetana mahavidyalay Aurangabad \\ *Email- agale.sir@gmail.com
}

\begin{abstract}
India has tremendous potential to cultivate onion on small as well as commercial scale. It is the most important cash crop cultivated in large part of country since ancient period. It plays vital role in human diet as well as medicinal importance. India is the second largest onion growing country in the world. In India major onion growing states are Maharashtra, Karnataka, Gujarat, Bihar, Madhya Pradesh, Andhra Pradesh, Rajasthan and Haryana. The tremendous climatic variations in the country make it possible to grow wide varieties of onion in different season. National Agricultural Research Centre and National Horticulture Research Development Foundation, National Agriculture Co-operative Marketing Federation (NAFED) and the Indian Council of Agricultural Research (ICAR) have taken efforts to systematic development of onion. In India onion is growing by two methods one is sowing and second is transplanting. It is produced in three different seasons namely, early kharif, Kharif and Rabi. Early kharif season starts from mid-June and harvesting is done in August - September. Kharif season starts from early September and harvested during the month of January. Rabi season is starts in the month of November - December and the harvested in the month of February and early March. The cultivation of onion can become economically profitable when get good price in market. Early kharif and kharif season onion is highly perishable so it sold in market at earlier, that time profit of farmer depends on market price. Sometime farmers get big loss due to price fluctuation. Rabi onion is semi-perishable it stores up to four to six months. It means that storage plays important role in marketing of onion. Storage facility and capacity depends on economic condition of farmer. Storage facility and capacity, labour, climatic hazards, export policy of Government, middleman and type of market these are the major problems of onion cultivation. But now a day the onion crop in trouble, the main reason is climate change. It has low productivity. The onion crop is unprofitable. Climate change is the major cause of low production of onion crop worldwide. Fog, dew, unseasonal rainfall, temperature variation, hail storm, cloudiness, this climatic phenomenon occurs due to the climate change. It is major causes to decrease the productivity of onion crop. The above climatic phenomenon invites the various diseases on the onion crop, like Damping-off, Purple Blotch, Onion Smut, Anthracnose, etc. that mean more uses of chemical fertilisers and pesticides, which is very costly. As well as, increasing temperature causes to more irrigation. These effects of climate change also influence the pest and disease occurrences, host-pathogen interactions, distribution and ecology of insects, time of appearance, migration to new places and their overwintering capacity, there by becoming major setback to onion cultivation. Climate change is imbalanced the onion agriculture.
\end{abstract}

Key words: - Systematic development, Climatic hazards, Middleman, Climate change, Productivity, Crop diseases

\section{INTRODUCTION}

Many developing countries are especially sensitive to climate change because they are located in the tropics, with temperatures that already compromise agricultural production (Da Cunha et al., 2015; Kurukulasuriya et al., 2006; Mendelsohn et al., 2006), and because they have limited access to the human and physical capital that might mitigate its effects (Di Falco,
2014). Climate change has been become world headache topic as well as major challenge to face especially in agriculture industry. In the next century, the global temperature could increase up to $4.8^{\circ} \mathrm{C}$ (IPCC, 2013) and if it rise by $2{ }^{\circ} \mathrm{C}$ or more the production of the world's major crops such as wheat, rice and maize onion will be disturb (IPCC, 2014). Over the last century the world temperature has increased 
which is $0.60 \mathrm{C}$. Climate change that mean change in the various element of weather such as temperature, precipitation, relative humidity and atmospheric gases composition etc. According to Schneider et al. (2007) vulnerability of any system to climate change is the degree to which these systems are susceptible and unable to survive with the adverse impacts of climate change. The changes in climate may include fluctuations in temperature, increase in soil salinity, water logging, high atmospheric $\mathrm{CO} 2$ concentration and UV radiation. High temperature is due to the increased amount of greenhouse gases like CO2and $\mathrm{CH} 4$ in atmosphere which is commonly known as global warming or greenhouse effect. The mean annual temperature of India is increased by $0.46 \mathrm{C}$ over a period of last 111 years since 1901 (24.230C) to 2012 (24.690C) (Data Portal India, 2013). Global combined surface temperatures over land and sea have been increased from $13.680 \mathrm{C}$ in 1881-90 to $14.470 \mathrm{C}$ in 2001-10 (WMO, 2013). Globally averaged surface temperature is expected to rise by between $1.1^{\circ} \mathrm{C}$ up to $6.4^{\circ} \mathrm{C}$ by the last decade of the 21 st century (Minaxi et al., 2011).

Climate change is the primary cause of low production of most of the vegetables worldwide; reducing average yields for most of the major vegetables. These effects of climate change also influence the pest and disease occurrences, host-pathogen interactions, distribution and ecology of insects, time of appearance, migration to new places and their overwintering capacity, there by becoming major setback to vegetable cultivation. Various diseases are become damage the crops, which diseases born by the climate change. Onion is mostly usable vegetable in their daily diet of all over world. These papers present the causes of climate change and its impact on the onion crop.

\section{DATABASE AND METHODOLOGY:}

The broad picture of present study with the help of secondary data Sources and used for period of 2000-01 to 2017-18 (17 years)

\section{Secondary data:}

$>$ Documental Records from: Agriculture and Irrigation Dept. Ahmednagar.

Census of India: Ahmednagar District Censes Hand book, 1991 and 2001, 2011 Census Governmental website, Gazetteer, SocioEconomic Abstract and Strategic Research and Extension Plan of Ahmednagar District,

> Mahatma Phule Krishi Vidyapeeth (Rahuri) and PIRENCE (Babhaleshwar) Research Institute Report, Project work, Research work etc.

> Reference Books, Other Published and unpublished Information's, various website etc.

\section{Causes of Climate change:}

$>$ Greenhouse gases

$>$ Burning coal, oil and gas

$>$ Global warming

$>$ Transportation

$>$ Deforestation

$>$ Industrialisation

$>$ Volcanoes

Global climate change has already had observable effects on the environment. Glaciers have shrunk, ice on rivers and lakes is breaking up earlier, plant and animal ranges have shifted and trees are flowering sooner, as well as its direct impact on agriculture. When increase the temperature there are more needs of irrigation for the crop. Due to the imbalance of weather or rise the temperature various micro-Bactria were born they can be damaging the crop.

Impact of climate change on onion crop: 
The onion plant has been grown and selectively bred in cultivation for at least 7,000 years. It mostly uses for diet, as well as medicine also. The climate change directly impacts on onion. Climate change impact on onion during the cultivation as well as storage. Humid climate can destroy storage onion. Lack of onion production danger for the food security.

The following diseases are occurred because of climate change

\section{Purple Blotch (Alternaria porri):}

It is an important disease prevalent in all the onion growing areas. Hot and humid climate with temperature ranging from $21-30^{\circ} \mathrm{C}$ and relative humidity $(80-90 \%)$ favour the development of the disease. It is more common in kharif season. The symptoms occur on leaves and flower stalks as small, sunken, whitish flecks with purple-coloured centres. The lesions may girdle leaves/stalk and cause their drooping. The infected plants fail to develop bulbs. The intensity of disease varies from season to season.

\section{Stemphylium Blight (Stemphylium vesicarium):}

The Stemphyliium blight is a serious problem in Northern parts of the country especially in the seed crop. This disease is very common on onion leaves and flower stalks. Infection occurs on radial leaves of transplanted seedlings at 3- 4 leaf stage during late March and early April. The symptoms appear as small yellowish to orange flecks or streaks in the middle of the leaves, which soon develop into elongated spindle shaped spots surrounded by pinkish margin. The disease appearing on the inflorescence stalk causes severe damage to the seed crop.

\section{Basal Rot (Fusarium oxysporum f.sp. cepae):}

The disease incidence is more in the area where onion crop is grown continuously. A moderate temperature of $22-28^{\circ} \mathrm{C}$ favours disease development. Initially yellowing of leaves and stunted growth of plant is observed and later on, the leaves dry from tip downwards. In early stage of infection, the roots of the plants become pink in colour and rotting take place later. In advanced stage, the bulb starts decaying from lower ends and ultimately whole plant die.

\section{Onion Smut (Urocystis cepulae):}

The disease occurs in areas where temperature remains below $30^{\circ} \mathrm{C}$. Since the fungus remains in soil, disease appears on the cotyledon of the young plant soon after it emerges. Smut appears as elongated dark, slightly thickened areas near the base of seedlings. The black lesions appear near the base of the scales on planting. The affected leaves bend downwards abnormally. On older plants, numerous raised blisters occur near the base of the leaves. The lesions on plant at all stages often expose a black powdery mass of spores.

\section{CONCLUSION:}

The changes in climate is a continuous process, it has become recognizable in agricultural field from the past few years when it has started significant and lasting effect on onion crop production. Effects of climate change generated by global warming on onion crop plants are the major among all the climate change effects. Therefore, we should be clearly known that the climate change has the large impact on food security in future. We should be changing our life style for nature and next generation because human also responsible for climate change. The farmers should be taking the cropping pattern according to climate.

\section{REFERENCES:}

Ahmad, J., D. Alam, and M. S. Haseen. 2011. Impact of Climate Change on Agriculture and Food Security in India. International Journal of Agriculture, Environment and Biotechnology 4(2):129-137. 
Arora, S.K., P.S. Partap, M.L. Pandita, and I. Jalal. 1987. Production problems and their possible remedies in vegetable crops. Indian Horticulture 32(2):2-8.

AVRDC. 1981. Annual Report. Asian Vegetable Research and Development Center. Shanhua, Taiwan. Pp:84.
AVRDC. 1990. Vegetable Production Training

Manual. Asian Vegetable Research and Training Center. Shanhua, Tainan, Pp:447.

various sources of internet
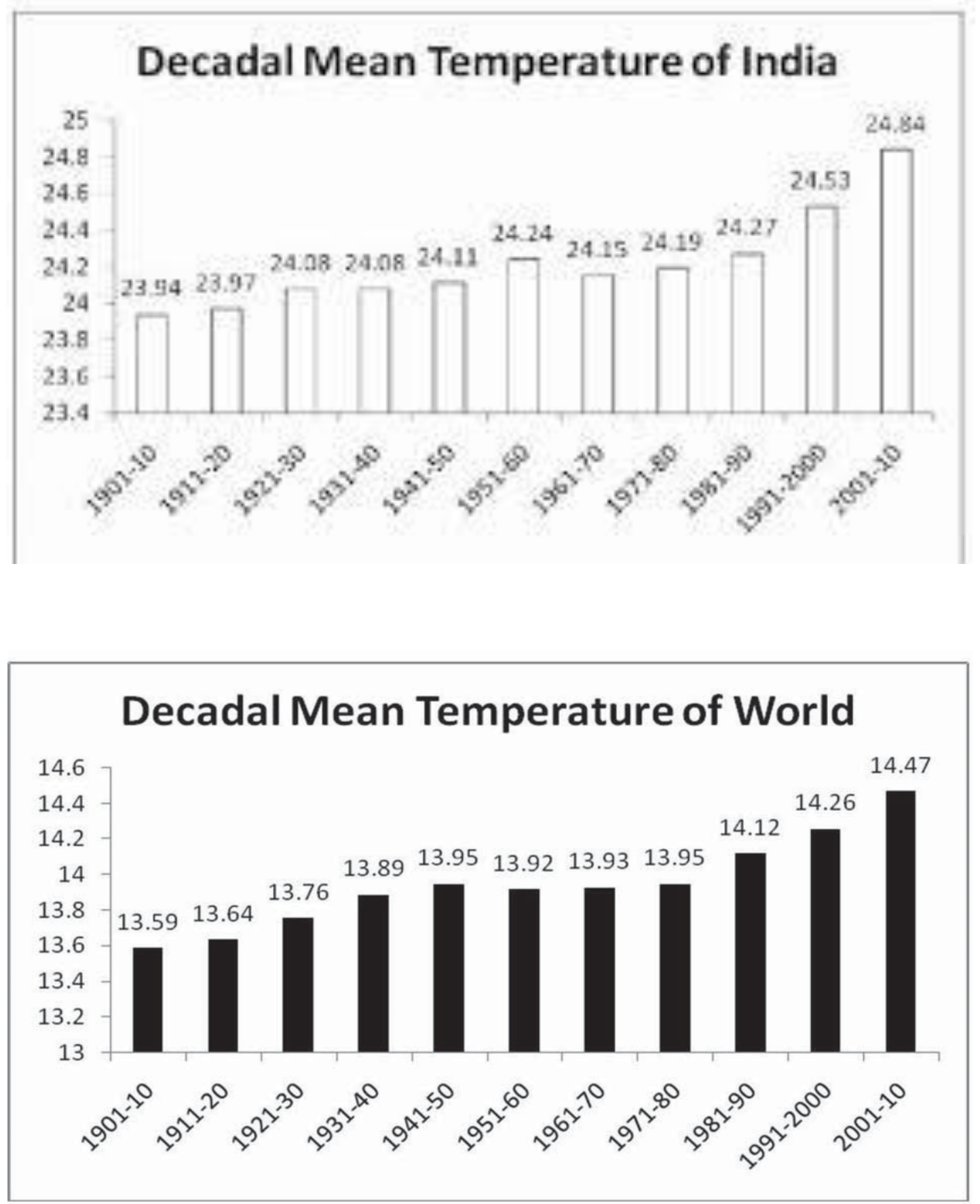

This both graphs show how to increase the temperature since 1901 to 2010 of all over the World as well as India. 